\title{
Soil Nematodes and Their Prokaryotic Prey Along an Elevation Gradient in The Mojave Desert (Death Valley National Park, California, USA)
}

\author{
Amy Treonis *, Kelsey Sutton, Brendan Kavanaugh, Archana Narla, Timothy McLlarky, \\ Jasmine Felder, Cecilia O'Leary, Megan Riley, Alyxandra Pikus and Sarah Thomas \\ Department of Biology, University of Richmond, Richmond, VA 23173, USA \\ * Author to whom correspondence should be addressed; E-Mail: atreonis @ richmond.edu; \\ Tel.: +1-804-287-6493; Fax: +1-804-289-8233.
}

Received: 27 August 2012; in revised form: 16 September 2012 / Accepted: 27 September2012 / Published: 15 October 2012

\begin{abstract}
We characterized soil communities in the Mojave Desert across an elevation gradient. Our goal was to test the hypothesis that as soil quality improved with increasing elevation (due to increased productivity), the diversity of soil prokaryotes and nematodes would also increase. Soil organic matter and soil moisture content increased with elevation as predicted. Soil salinity did not correlate to elevation, but was highest at a mid-gradient, alluvial site. Soil nematode density, community trophic structure, and diversity did not show patterns related to elevation. Similar results were obtained for diversity of bacteria and archaea. Relationships between soil properties, nematode communities, and prokaryotic diversity were site-specific. For example, at the lowest elevation site, nematode communities contained a high proportion of fungal-feeding species and diversity of bacteria was lowest. At a high-salinity site, nematode density was highest, and overall, nematode density showed an unexpected, positive correlation to salinity. At the highest elevation site, nematode density and species richness were attenuated, despite relatively high moisture and organic matter content for the soils. Our results support emerging evidence for the lack of a relationship between productivity and the diversity of soil nematodes and prokaryotes.
\end{abstract}

Keywords: archaea; bacteria; diversity; hot desert; nematodes; PCR-DGGE; productivity; species richness 


\section{Introduction}

The diversity of soil organisms is both massive and relatively poorly understood [1,2]. Conventionally, species diversity is thought to be related to the productivity of a habitat [3], which is determined primarily by abiotic factors such as rainfall and temperature [4]. However, recent studies of soil communities suggest that soil biota and microorganisms may not share diversity patterns often exhibited by plants and animals [5-7].

We characterized the relationship between soil prokaryotic and nematode diversity at six sites in Death Valley National Park (Mojave Desert, California, USA). The Park includes the largest elevation gradient in the contiguous United States, ranging from the Badwater Basin at $86 \mathrm{~m}$ below sea level to Telescope Peak at 3,368 m above sea level (m.a.s.1.). The North American temperature record was measured in Death Valley in $1913\left(56.7^{\circ} \mathrm{C}\right)$, and daytime temperatures at the lower elevations exceed $37{ }^{\circ} \mathrm{C}$ daily from May to September, on average. Annual rainfall is generally less than $3 \mathrm{~cm}$ at the lowest elevation but can exceed $40 \mathrm{~cm}$ at higher locations [8]. Death Valley National Park is a particularly valuable field site because natural variation in productivity exists within a small geographic area due to the large elevation change. Furthermore, a common plant species exists throughout much of the ecosystem (Larrea tridentata, creosotebush) so that the influence of varying plant species can be limited when sampling between sites.

We hypothesized that as soil quality improved with increasing elevation, the diversity of soil prokaryotes and the abundance and diversity of nematodes would also increase. We focused this study on communities within the surface soils beneath $L$. tridentata canopies. These resource islands are where significant decomposition and nutrient generation occur in desert ecosystems [9,10]. We included both bacteria and archaea in our analyses, as both are prey for the bacteria-feeding nematodes that dominate these communities [11,12], and archaea are increasingly recognized for their contribution to soil communities [13].

\section{Results and Discussion}

The six sites sampled in Death Valley National Park represented an elevation gradient ( -8 to 1,610 m.a.s.1.), but the sites also varied with respect to un-quantified slope, mineralogy, and alluvial influences. Despite these potentially confounding factors, soils exhibited a significant gradient of improving quality with increasing elevation and amelioration of extreme environmental conditions. Soil organic matter and moisture content both increased with elevation as predicted, and soil $\mathrm{pH}$ decreased (Table 1). Soil organic matter content was low overall, as is typical of desert soils [10], ranging from $0.46-4.45 \%$ (Table 1). Soil moisture content was low as well, ranging from $0.16-6.2 \%$, and varied between sites significantly (Table 1). Moisture content generally increased with elevation, but the second highest site at 1,010 m.a.s.l. had the highest mean moisture content (Table 1). Soil pH varied significantly between sites (Table 1) and decreased with increasing elevation. Desert soils usually have a slightly basic $\mathrm{pH}$ [10], and the decrease with elevation and corresponding increases in moisture and organic matter reflect soils becoming less desert-like.

Soil respiration rates during laboratory incubations (a measure of potential heterotrophic activity) did not vary significantly between sites. Electrical conductivity, a measure of salinity, did not vary, 
with the exception of the Darwin Falls site at 752 m.a.s.1., which was significantly more saline than all the other field sites (Table 1). This location is alluvial and likely experiences salt deposition due to evaporation of ephemeral stream water.

Table 1. Soil properties for Death Valley field sites*.

\begin{tabular}{lcccccc}
\hline \multicolumn{1}{c}{ Site } & $\begin{array}{c}\text { Elevation } \\
(\mathbf{m . a . s . l .})\end{array}$ & $\begin{array}{c}\text { Organic Matter } \\
(\boldsymbol{\%}, \mathbf{L O I})\end{array}$ & $\begin{array}{c}\text { Gravimetric Soil } \\
\text { Moisture }(\boldsymbol{\%})\end{array}$ & $\begin{array}{c}\mathbf{p H} \\
* * *\end{array}$ & $\begin{array}{c}\text { EC }(\boldsymbol{\mu S}) \\
* * * *\end{array}$ & $\begin{array}{c}\text { Respiration } \\
\left(\mathbf{C O}_{\mathbf{2}} \boldsymbol{\mu \mathbf { m o l }}\right. \\
\end{array}$ \\
\hline Sand Dunes & -8 & $0.62 \pm 0.07 \mathrm{a}$ & $0.18 \pm 0.006 \mathrm{a}$ & $8.66 \pm 0.05 \mathrm{a}$ & $183.88 \pm 18.76 \mathrm{a}$ & $0.12 \pm 0.02 \mathrm{a}$ \\
Unnamed Site & 152 & $1.40 \pm 0.10 \mathrm{~b}$ & $0.48 \pm 0.029 \mathrm{ab}$ & $8.40 \pm 0.04 \mathrm{ab}$ & $189.63 \pm 18.55 \mathrm{a}$ & $0.13 \pm 0.01 \mathrm{a}$ \\
Jubilee Pass & 394 & $1.97 \pm 0.16 \mathrm{bc}$ & $0.89 \pm 0.080 \mathrm{bc}$ & $8.12 \pm 0.08 \mathrm{bcd}$ & $176.25 \pm 15.72 \mathrm{a}$ & $0.10 \pm 0.01 \mathrm{a}$ \\
Darwin Falls & 752 & $2.27 \pm 0.38 \mathrm{c}$ & $0.97 \pm 0.18 \mathrm{bc}$ & $8.03 \pm 0.20 \mathrm{~cd}$ & $667.00 \pm 169.10 \mathrm{~b}$ & $0.16 \pm 0.03 \mathrm{a}$ \\
SalsberryPass & 1010 & $3.11 \pm 0.18 \mathrm{~d}$ & $2.71 \pm 0.53 \mathrm{~d}$ & $8.22 \pm 0.08 \mathrm{bc}$ & $241.63 \pm 31.85 \mathrm{a}$ & $0.13 \pm 0.03 \mathrm{a}$ \\
Dantes View & 1610 & $3.71 \pm 0.22 \mathrm{~d}$ & $1.50 \pm 0.12 \mathrm{c}$ & $7.84 \pm 0.07 \mathrm{~d}$ & $355.13 \pm 44.12 \mathrm{a}$ & $0.12 \pm 0.02 \mathrm{a}$ \\
\hline
\end{tabular}

* Values are means \pm the standard error of the mean $(n=8)$. Within each column, values with different letters are significantly different; ** m.a.s.l. = meters above sea level; *** (ANOVA, $P \leq 0.0001)$; $* * * *$ No significant differences (ANOVA, $P=0.65$ ).

Nematode density varied significantly between sites, but these differences were not related to elevation (Figure 1a). Soils from $-8,752$ and 1,010 m.a.s.l. contained the highest densities of nematodes. Nematode density across the samples varied from $110-9,151 \mathrm{~kg}^{-1}$ soil.

Polymerase chain reaction-denaturing gradient gel electrophoresis (PCR-DGGE, [14]) of amplified ribosomal DNA from soil nematodes was used to assess the relative species richness of nematode communities. The number of distinct electrophoresis bands obtained for each sample was used as an estimate of richness. DGGE underestimates community richness due, in part, to the inability to resolve overlapping bands $[15,16]$. However, the technique is a simple and useful method for making relative assessments between communities [17-19]. Nematode species richness data was not analyzed statistically because nematodes extracted from site replicates were pooled in order to maximize representation of all species. However, there does not appear to be any trend in the data relating to elevation. The highest elevation site did have a markedly lower number of bands than the other sites (Figure 1b). Few studies have studied nematode diversity along productivity gradients, but Barrett and colleagues [5] found soil nematode diversity and abundance to be mostly unrelated to organic content in soils collected in the Antarctic Dry Valleys, at several field sites with varying latitude and productivity. 
Figure 1. Nematode communities in soils from Death Valley field sites. (a) Nematode density; (b) Relative species richness of nematode communities; (c) Relative proportion of trophic groups in the communities. Values represent means \pm the standard error of the mean $(n=8)$. For (a) and (c), bars with different letters are significantly different (ANOVA, $P \leq 0.005$, Fisher's PLSD).
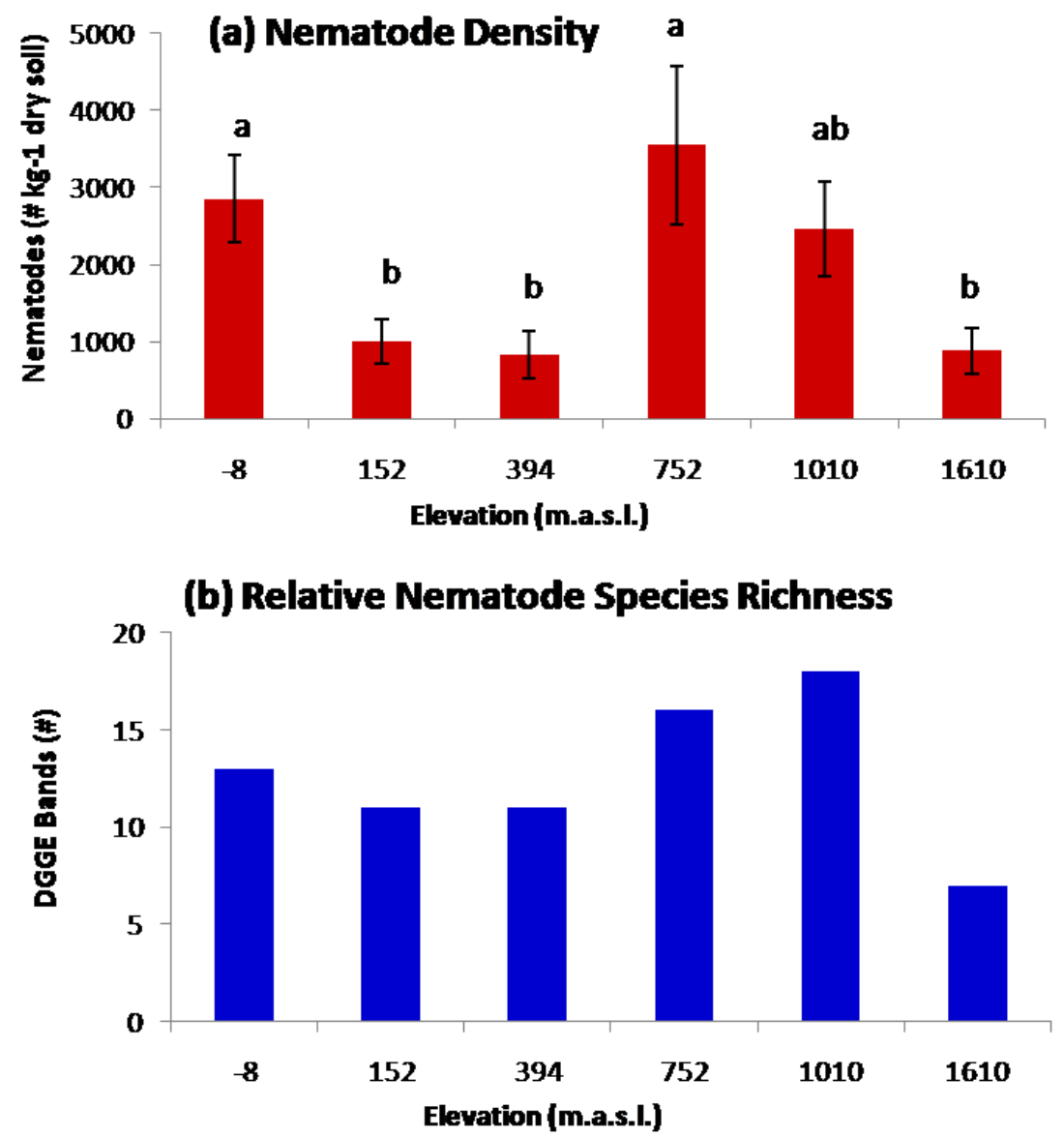

(c) Nematode Trophic Groups

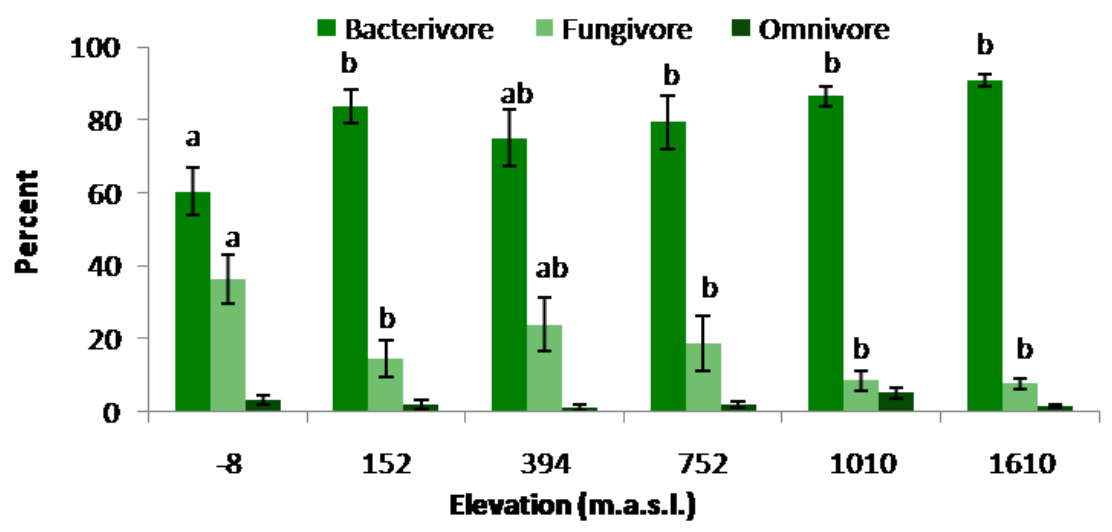

Nematode community structure varied between the sites (Figure 1c). Bacteria-feeding and fungalfeeding species dominated the nematode communities at all locations, consistent with prior work on Mojave Desert soils [11]. The main groups of bacteria-feeders encountered were from the Cephalobidae family (Acrobeles, Acrobeloides, Cephalobus spp.), but Plectidae and Rhabtididae were 
also found. The main groups of fungal-feeders found were Anguinidae (Ditylenchus sp.) and Aphelenchidae/Aphelenchoididae. Omnivorous species made a small contribution to the communities, and did not vary significantly between sites (Figure 1c). Freckman and Mankau [11] studied soil nematode communities beneath L. tridentata in the Mojave Desert (Rock Valley, Nevada) and found plant-parasitic species in their samples, which we did not. These researchers sampled from a depth of 0-10 cm, whereas we confined our analyses to $0-5 \mathrm{~cm}$. Plant-parasitic nematode species abundances are known to increase with depth in arid ecosystems, following the distribution of plant roots [20], so it seems likely that they would be found in Death Valley in deeper soil layers.

We found that bacteria-feeding nematode species generally were the most abundant across the sites, ranging from $36-98 \%$ of the nematodes found in each sample. Their contribution to the total community was lowest at the lowest elevation site ( -8 m.a.s.l., Figure $1 \mathrm{c})$. In tandem, the proportional representation of fungal-feeding species was significantly higher at -8 m.a.s.l. than at higher elevations (Figure 1c). The higher relative abundance of fungal-feeding nematodes at the lowest elevation was surprising, as was the high overall abundance of nematodes there. These results suggest that fungal-feeding nematodes (and likely fungi as well) flourish under the extreme conditions at that site, relative to bacteria-feeding nematodes. A common nematode genera encountered, Aphelenchus, is known to have excellent survival capabilities through its use of an anhydrobiotic strategy that has also been demonstrated for many bacteria-feeding nematode species [21,22]. In anhydrobiosis, or "life without water", nematodes survive desiccating conditions in an ametabolic state [23]. In the cold desert soils of the Antarctic Dry Valleys, a single species of nematode, Scottnema lindsayae, has a broad distribution and high abundance relative to the few other nematode species found in this ecosystem [24,25]. This nematode appears to be a dry soil specialist, facilitated by its ability to use anhydrobiosis [22]. Nematode species in Death Valley soils likely are similarly adapted such that the extreme desiccation and low productivity of low elevation soils do not limit their distribution. The ability to use anhydrobiosis may be widespread among nematode species, allowing them to survive and maintain high densities even in the arid core of Death Valley.

Nematode communities have been studied in the Judean Desert (Israel), along a transect encompassing 650 to -60 m.a.s.l. [26]. Here, nematode density declined with decreasing elevation and soil moisture content. Nematode diversity was unrelated to elevation, however, and shifts in trophic structure were not observed. In the Antarctic Dry Valleys, nematode communities were found with highest diversity at the lowest elevation sites, and diversity and abundance declined with elevation over 83-188 m.a.s.1. [27]. At this site, soil moisture and organic matter were highest at the lowest elevations and decline moving upwards. The contrast between the results of these studies of desert nematode communities and the results of our study suggests the importance of site-specific factors in structuring nematode communities.

Relative species richness of bacteria, as estimated by the number of bands produced via DGGE analysis, was higher than that of archaea at all field sites (Figure 2). Bacteria richness varied significantly between sites, with the highest diversity found at 394 m.a.s.l. and the lowest at -8 m.a.s.l. (Figure 2a). Archaea richness did not vary significantly among the field sites (Figure 2b). Bryant and colleagues [28] demonstrated a negative linear trend in soil Acidobacteria richness with increasing elevation at sites (2,460-3,380 m.a.s.l.) in the Rocky Mountains (Colorado, USA). Singh and colleagues [29] demonstrated a hump-shaped soil bacteria diversity pattern on Mt. Fiji (Japan) over 
1,000-3,760 m.a.s.1., with the lowest diversity at the highest elevations. In both of these studies, environmental conditions deteriorated with increasing elevation (opposite to our Death Valley sites), and communities with the lowest diversity were found under the most extreme conditions, as seen in our study. Recent work by Fierer and colleagues [6], however, failed to demonstrate any elevation gradient with respect to bacterial phylotype richness across a comprehensive 200-3,400 m.a.s.1. elevation transect in Peru. It appears that prokaryotic communities may not follow the same diversity patterns as those exhibited by animals and plants, yet whether these communities exhibit any patterns in relation to productivity remains to be clearly demonstrated.

Figure 2. Relative species richness of prokaryotic communities among the field sites: (a) Bacteria, (b) Archaea. Values represent the mean number of DGGE bands enumerated from samples from each site \pm the standard error of the mean $(n=8)$. Bars with different letters are significantly different (ANOVA, $P<0.0001$, Fisher's PLSD). No statistical differences were detected for Archaea $(P=0.18)$.

\section{(a) Relative Species Richness of Bacteria}

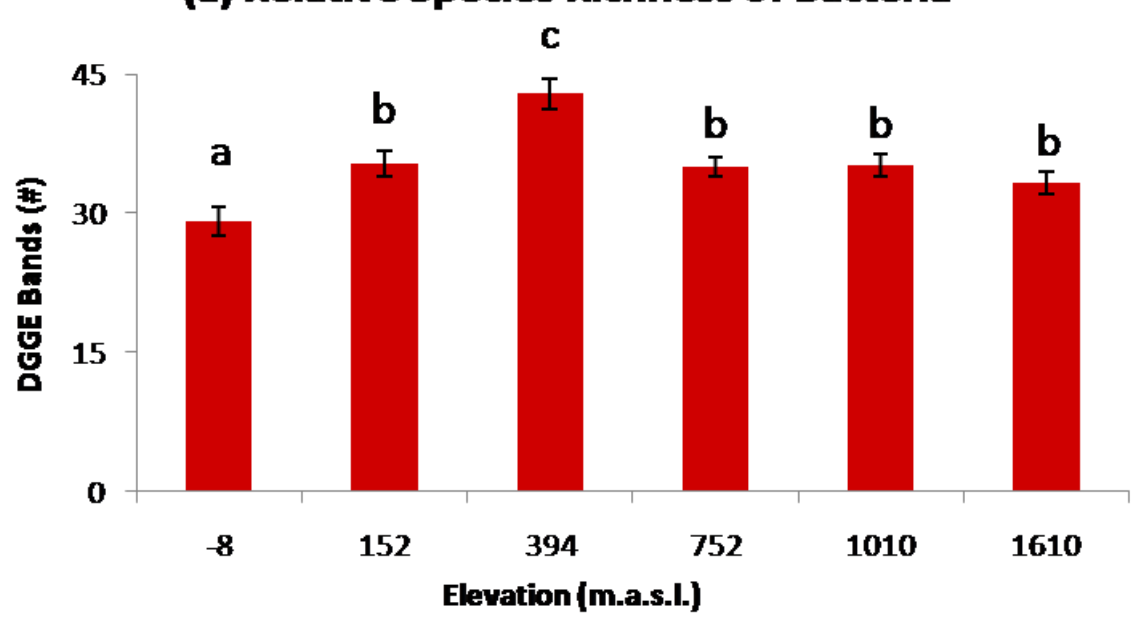

(b) Relative Species Richness

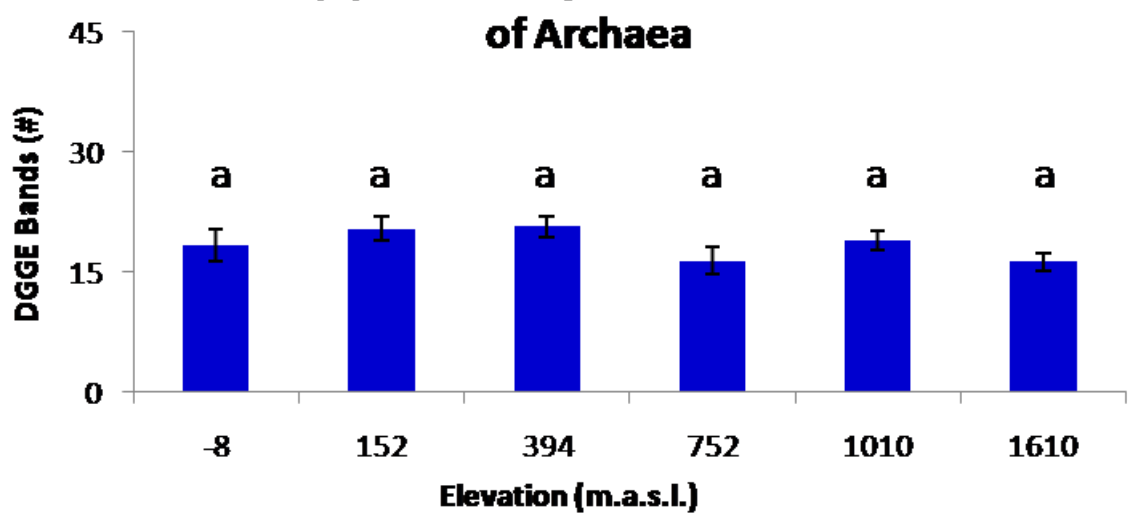

Overall, relationships between soil properties, nematode communities, and prokaryotic diversity were site-specific in Death Valley and did not demonstrate patterns related to elevation. Desert soils are often saline due to low precipitation and the accumulation of salts through weathering and 
atmospheric deposition. High salinities have been shown to be sufficient to exclude soil microfauna in other ecosystems. Treonis and colleagues [24] found nematodes were absent from Antarctic Dry Valley soils with salinities greater than $2,500 \mu \mathrm{S}$. In Death Valley, the highest salinity measured was $1,401 \mu \mathrm{S}$ and well below values found in Antarctica. Further, we found a significant positive correlation between electrical conductivity and nematode density in the Death Valley soils studied (Table 2). This relationship is likely to be indirect. High salinity soils in Death Valley were located at the 752 m.a.s.l. Darwin Falls site. Darwin Falls is one of only four perennial streams in Death Valley National Park, and while we sampled beyond the terminus of the stream, it is likely that the soils we sampled receive overflow stream water during rainstorms. These ephemeral moisture pulses could contribute to increasing soil salinity but also promote the establishment of higher density nematode communities (Figure 1).

In contrast to nematode density, electrical conductivity and archaea richness were negatively correlated across our Death Valley samples (Table 2). Archaea have been associated with extreme environments, and several taxa are known for their halophilic nature [30]. Archaeal distribution is cosmopolitan in soils [31], however, and none of the soils we studied represent extremes of salinity. Archaea carry out important processes (e.g., methanogenesis) and have been shown to be prey for microbivorous nematodes [12]. In Death Valley, their diversity may be negatively influenced by salinity in an unanticipated manner that warrants further research.

Table 2. Correlation between soil properties and nematode and prokaryote communities*.

\begin{tabular}{lccc}
\hline \multicolumn{1}{c}{ Soil Property } & Nematode Density & Bacteria Diversity & Archaea Diversity \\
\hline Moisture & 0.43 & 0.26 & 0.45 \\
Organic Matter & 0.38 & 0.29 & 0.29 \\
Electrical Conductivity & $0.0028 * *$ & 0.36 & $0.023 * * *$ \\
$\mathrm{pH}$ & 0.21 & 0.097 & 0.407 \\
\hline$*$ Values are $P$-values for correlation analyses $(\mathrm{n}=48) ; * *$ Correlation was positive $(0.39) ;$ \\
$* * *$ Correlation was negative $(-0.29)$.
\end{tabular}

The diversity and abundance of consumer organisms such as soil nematodes is likely influenced by the diversity and abundance of food sources available to them [32], as niche differentiation is an important driver of species co-existence [33]. We were unable to establish a relationship between nematode diversity and that of their prokaryotic prey in Death Valley soils, however. Barrett and colleagues [5] studied nematodes and bacterial diversity in the polar desert soils of the Antarctic Dry Valleys, where a relationship between bacterial richness and nematode density was also not apparent. In our study, at our highest elevation site in Death Valley, nematode density and species richness were attenuated and prokaryotic diversity was moderate, despite relatively high moisture and organic matter content for the soils. It is clear that other factors aside from elevation and soil quality influence the diversity of soil organisms in desert soils.

\section{Experimental Section}

Soil samples were collected April 2010 from six sites within Death Valley National Park (Table 1) that encompass an elevation gradient ranging from -8 to 1,610 m.a.s.l. (the highest elevation at which 
L. tridentata was found). For each sample, approximately $1.5 \mathrm{~kg}$ of soil was collected from multiple locations within the canopy of the dominant plant species (L. tridentata). The soils at most of these locations are extremely rocky, limiting the ability to collect soil using a soil corer. Samples were thereby collected using 50-mL plastic beakers as scoops. Surface litter was scraped away and then soil was collected from $0-5 \mathrm{~cm}$. Soil was sieved $(2 \mathrm{~mm})$ on site to remove rocks and large pieces of litter and then transferred to a plastic bag (Whirl-Pak ${ }^{\circledR}$, Nasco, Fort Atkinson, WI). At each site, eight replicate samples were collected from eight individual shrubs within $100 \mathrm{~m}$ of each other. Soil samples were shipped in coolers from Las Vegas, NV to the University of Richmond and stored at $4{ }^{\circ} \mathrm{C}$ until analyzed.

Soil moisture was determined gravimetrically ( $48 \mathrm{~h}$ at $105{ }^{\circ} \mathrm{C}$ ), and electrical conductivity (EC), used as an indicator of salinity, was measured on a 1:3 soil:water slurry. Soil organic matter was measured as loss on ignition (LOI, $400{ }^{\circ} \mathrm{C}, 12 \mathrm{~h}$ ). Relative soil respiration rates (i.e., $\mathrm{CO}_{2}$ evolution) were determined by incubating $50 \mathrm{~g}$ soil samples at $22{ }^{\circ} \mathrm{C}$ inside of sealed pint-sized glass jars $(473 \mathrm{~mL})$. At the end of the incubation period $(8 \mathrm{~d})$, the $\mathrm{CO}_{2}$ concentration of a $25-\mathrm{mL}$ headspace gas sample, withdrawn from each jar through a septum in the lid using a syringe, was determined using an infrared gas analyzer (LI-820, LI-COR, Inc., Lincoln, NE, USA [34]).

A Baermann funnel technique was used to extract nematodes from $100 \pm 0.1 \mathrm{~g}$ soil at room temperature over $72 \mathrm{~h}$ [35]. Nematodes were fixed in $5 \%$ formalin solution for future enumeration. An inverted microscope was used to count the total number of nematodes per sample. Nematodes (200 per sample, as available) were assigned to trophic groups based on morphology [36].

Nematodes also were extracted from $100 \mathrm{~g}$ of soil using sucrose flotation and centrifugation technique [37]. The extracted nematodes from each of the eight replicates from each field site were combined for DNA extraction and analyses. A preliminary effort determined that this step was necessary in order to obtain adequate DNA and representation of diversity in the samples. Unfortunately, not enough collected soil was available for extraction from more than $100 \mathrm{~g}$ from each individual replicate. Following pooling and reduction of nematode samples to a small volume $(\approx 0.5 \mu \mathrm{L})$, nematode DNA was extracted and purified using the MO BIO Powersoil ${ }^{\mathrm{TM}}$ DNA Isolation kit (MO BIO Laboratories Inc., Carlsbad, CA, USA) following the manufacturer's instructions. A fragment of the 18S rDNA gene was amplified using the primers SSU18A and SSU9RGC [38] and the procedure of Okada and Oba [39]. A GC-clamp was added to the 5' end of the reverse primer SSU9RGC (CGCCCGCCGCGCGCGGCGGGCGGGGCGGGGGCACGGGGGG; 14). Reactions were carried out in a BioRad PTC-1148 Minicycler (Bio-Rad Laboratories, Hercules, CA, USA) with an initial denaturing step at $98{ }^{\circ} \mathrm{C}$ for $3 \mathrm{~min}, 27$ cycles of denaturing at $98{ }^{\circ} \mathrm{C}$ for $10 \mathrm{~s}$, annealing at $54{ }^{\circ} \mathrm{C}$ for $15 \mathrm{~s}$, and extension at $72{ }^{\circ} \mathrm{C}$ for $40 \mathrm{~s}$, and final extension at $72{ }^{\circ} \mathrm{C}$ for $10 \mathrm{~min}$.

PCR products were used for denaturing gradient gel electrophoresis (DGGE [14]) using the BioRad DCode Universal Mutation Detection System (Bio-Rad Laboratories, Hercules, CA, USA). An 6\% ( $\mathrm{w} \mathrm{v}^{-1}$ ) polyacrylamide gel with a parallel denaturing gradient between $20 \%-50 \%$ (where $100 \%$ denaturant contains $7 \mathrm{M}$ urea and 40\% formamide) was cast using a GM-40 Gradient Maker (CBS Scientific Co., Del Mar, CA, USA) and an MPP-100 Mini Peristaltic Pump (CBS Scientific Co.) set at medium speed. $20 \mu \mathrm{L}$ of PCR product ( $\approx 400 \mathrm{ng}$ DNA) was mixed with $20 \mu \mathrm{L} 2 \times$ gel loading dye $(0.05 \%$ bromophenol blue, $0.05 \%$ xylene cyanol, $70 \%$ glycerol) and loaded into the gels. Electrophoresis was performed in $1 \mathrm{X}$ TAE at $60{ }^{\circ} \mathrm{C}$ for $16 \mathrm{~h}$ at $75 \mathrm{~V}$. The gel was stained in approximately $350 \mathrm{~mL} 1 \mathrm{X}$ TAE containing 5 
$\mu \mathrm{L}$ ethidium bromide $\left(10 \mathrm{mg} \mathrm{mL}^{-1}\right.$ ) on a platform shaker at $25 \mathrm{rpm}$ for $30 \mathrm{~min}$, followed by destaining in water $(2 \times, 15 \mathrm{~min})$. The gel was photographed using a Gel Logic 200 photodocumentation system (Kodak/Carestream Health Inc., Rochester, NY, USA). Bands in each lane were quantified visually on a computer monitor.

Total DNA was extracted and purified from $0.25 \mathrm{~g}$ soil samples from each of the eight replicates from each of the six field sites as described above. For analysis of bacteria species richness, a nested PCR technique was used to amplify a $177 \mathrm{bp}$ segment of the V3 hypervariable region of the bacterial 16S rDNA using the primer sets GM3F/GM4R [40] and EUB341GC/UNIV518R [14]. A GC-clamp was added to the 5' end of the forward primer EUB341GC, (CGCCCGCCGCGCGCGGCGGGGGGGCGGGGGCACGGGGGG; 14). The PCR procedure for GM3F/GM4R consisted of an initial denaturing step at $95{ }^{\circ} \mathrm{C}$ for $5 \mathrm{~min}, 30$ cycles of denaturing at $94{ }^{\circ} \mathrm{C}$ for $1 \mathrm{~min}$, annealing at $50{ }^{\circ} \mathrm{C}$ for 1 min, and extension at $72{ }^{\circ} \mathrm{C}$ for $1.5 \mathrm{~min}$, and final extension at $72{ }^{\circ} \mathrm{C}$ for $10 \mathrm{~min}$. The PCR procedure for EUB341GC/UNIV518R was the same as for GM3F/GM4R, apart from an annealing temperature of $60^{\circ} \mathrm{C}$ and an extension time of 1 min per cycle.

For analysis of archaea richness, a nested PCR procedure used was as described by [41] using the primers 21F/958R [42] and 344FGC/517R [43] to amplify a 192 bp fragment of the 16S rDNA. A GCclamp was added to the 5' end of the forward primer 344FGC (CGCCCGCCGCGCGCGGCGGGCGGGGCGGGGGCACGGGGGG; 14). The PCR procedure for 21F/958R consisted of an initial denaturing step at $95{ }^{\circ} \mathrm{C}$ for $5 \mathrm{~min}, 30$ cycles of denaturing at $95{ }^{\circ} \mathrm{C}$ for $1.5 \mathrm{~min}$, annealing at $55{ }^{\circ} \mathrm{C}$ for $1.5 \mathrm{~min}$, and extension at $72{ }^{\circ} \mathrm{C}$ for $1.5 \mathrm{~min}$, and final extension at $72{ }^{\circ} \mathrm{C}$ for $10 \mathrm{~min}$. The PCR procedure for 344FGC/517R was a touchdown method that began with an initial denaturing step at $94{ }^{\circ} \mathrm{C}$ for $3.5 \mathrm{~min}$, followed by denaturing at $94{ }^{\circ} \mathrm{C}$ for $45 \mathrm{~s}$, then annealing for $45 \mathrm{~s}$ at $65-55{ }^{\circ} \mathrm{C}$ (stepping down one degree every two cycles from 65 to $62{ }^{\circ} \mathrm{C}$ and one degree per cycle from 62 to $55^{\circ} \mathrm{C}$ ) and extension at $72{ }^{\circ} \mathrm{C}$ for $30 \mathrm{~s}$. This was followed by 30 cycles of denaturing at $94{ }^{\circ} \mathrm{C}$ for $45 \mathrm{~s}$, annealing at $55^{\circ} \mathrm{C}$ for $45 \mathrm{~s}$, and extension at $72{ }^{\circ} \mathrm{C}$ for $30 \mathrm{~s}$ with a $5 \mathrm{~min}$ extension on the final cycle.

PCR products were subjected to DGGE. For the bacteria, an $8 \%\left(\mathrm{w} \mathrm{v}^{-1}\right)$ polyacrylamide gel with a parallel denaturing gradient between $35-65 \%$ was cast and loaded with $20 \mu \mathrm{L}$ of PCR product as described above $\left(\approx 700 \mathrm{ng}\right.$ DNA). Electrophoresis of the bacteria gels was performed in $1 \times \mathrm{TAE}$ at $60{ }^{\circ} \mathrm{C}$ for $16.5 \mathrm{~h}$ at $75 \mathrm{~V}$. For the archaea gels, $7 \%\left(\mathrm{w} \mathrm{v}^{-1}\right)$ polyacrylamide and $40 \%-65 \%$ gradient, $20 \mu \mathrm{L}$ of PCR product was loaded $(\approx 300 \mathrm{ng}$ DNA), and electrophoresis was performed at $47 \mathrm{~V}$ for $16 \mathrm{~h}$. Bacterial and archaea DGGE gels were stained and analyzed as described above.

All statistical analyses were performed with Statview Version 5.0.01 (SAS Institute, Inc., Cary, NC, USA). Measured variables were compared between sites using one-factor analysis of variance (site only). The correlations between soil properties and nematode density, community trophic structure, and prokaryotic richness were explored through construction of a Pearsons Correlation Matrix. 


\section{Conclusions}

In this study, we explored the relationship between productivity and the diversity of soil nematodes and their prokaryotic prey in desert soils. Overall, the gradient studied shows improving soil quality with increasing elevation, likely due to increased plant productivity and belowground inputs as the extreme environmental conditions ameliorate. However, our results fail to support the hypothesis that there is a positive relationship between diversity and productivity in soil communities, which is consistent with emerging research by others.

\section{Acknowledgments}

We thank Emily Archibald, Blake Bailey, Emily Boone, Charles Parsons, Lori Spicer, and Gabriela Timoney for assistance with sampling and laboratory work. Two anonymous reviewers are thanked for their comments. This research was supported by a Science Education grant to the University of Richmond from the Howard Hughes Medical Institute.

\section{References}

1. Bardgett, R.D.; Yeates, G.W.; Anderson, J.M. Patterns and determinants of soil biological diversity. In Biological Diversity and Function in Soil; Bardgett, R.D., Usher, M.B., Eds.; Cambridge University Press: Cambridge, UK, 2005; pp. 100-118.

2. Fierer, N.; Jackson, R.B. The diversity and biogeography of soil bacterial communities. Proc. Natl. Acad. Sci. USA 2006, 103, 626-631.

3. Waide, R.B.; Willig, M.R.; Steiner, C.F.; Mittelbach, G.; Gough, L.; Dodson, S.I.; Juday, G.P.; Parmenter, R. The relationship between productivity and species richness. Ann. Rev. Ecol. Syst. 1999, 30, 257-300.

4. Rosenzweig, M.L. Net primary productivity of terrestrial communities: predictions from climatological data. Am. Nat. 1968, 102, 67-74.

5. Barrett, J.E.; Virginia, R.A.; Wall, D.H.; Cary, S.C.; Adams, B.J.; Hacker, A.L.; Aislabie, J.M. Co-variation in soil biodiversity and biogeochemistry in Northern and Southern Victoria Land, Antarctica. Antarct. Sci. 2006, 18, 535-548.

6. Fierer, N.; McCain, C.M.; Meir, P.; Zimmermann, M.; Rapp, J.M.; Silman, M.R.; Knight, R. Microbes do not follow the elevational diversity patterns of plants and animals. Ecology 2011, 92, 797-804.

7. Wu, T.; Ayres, E.; Bardgett, R.D.; Wall, D.H.; Garey, J.R. A molecular study of the worldwide distribution and diversity of soil animals. Proc. Natl. Acad. Sci. USA 2011, 108, 17720-17725.

8. Death Valley National Park Homepage. Available online: http://www.nps.gov/deva (accessed on 11 August 2012).

9. Titus, J.H.; Nowakw, R.S.; Smith, S.D. Soil resource heterogeneity in the Mojave Desert. J. Arid Environ. 2002, 52, 269-292.

10. Whitford, W.G. Ecology of Desert Systems; Academic Press: San Diego, CA, USA, 2002.

11. Freckman, D.W.; Mankau, R. Distribution and trophic structure of nematodes in desert soils. Ecol. Bull. 1977, 25, 511-514. 
12. Treonis, A.M.; Michelle, E.H.; O’Leary, C.A.; Austin, E.E.; Marks, C.B. Identification and localization of food source microbial nucleic acids inside soil nematodes. Soil Biol. Biochem. 2010, 42, 2005-2011.

13. Bates, S.; Caporaso, J.G.; Walters, W.A.; Knight, R.; Fierer, N. Examining the global distribution of dominant archaeal populations in soil. ISME J. 2011, 5, 908-917.

14. Muyzer, G.; Dewaal, E.C.; Uitterlinden, A.G. Profiling of complex microbial-populations by denaturing gradient gel electrophoresis analysis of polymerase chain reaction-amplified genes coding for 16S rRNA. Appl. Environ. Microb. 1993, 59, 695-700.

15. Øvreås, L.; Jensen, S.; Daae, F.L.; Torsvik, V. Microbial community changes in a perturbed agricultural soil investigated by molecular and physiological approaches. Appl. Environ. Microb. 1998, 64, 2739-2742.

16. Oros-Sichler, M.; Costa, R.; Heuer, H.; Smalla, K. Molecular fingerprinting techniques to analyze soil microbial communities. In Modern Soil Microbiology, 2nd ed.; Elsas, J.D.V., Jansson, J.K., Trevors, J.T., Eds.; CRC Press: Boca Raton, FL, USA, 2006; pp. 355-377.

17. Foucher, A.L.J.L.; Bongers, T.; Noble, L.R.; Wilson, M.J. Assessment of nematode biodiversity using DGGE of 18S rDNA following extraction of nematodes from soil. Soil Biol. Biochem. 2004, $36,2027-2032$.

18. Takemoto, S.; Niwa, S.; Okada, H. Effect of Storage Temperature on Soil Nematode Community Structures as Revealed by PCR-DGGE. J. Nematol. 2010, 42, 324-331.

19. Wang, J.; Yang, D.; Zhang, Y.; Shen, J.; van der Gast, C.; Hahn, M.W.; Wu, Q. Do patterns of bacterial diversity along salinity gradients differ from those observed for macroorganisms? PLoS One 2011, 6, 1-8.

20. Freckman, D.W.; Virginia, R.A. Plant-feeding nematodes in deep-rooting desert ecosystems. Ecology 1989, 70, 1665-1678.

21. Madin, K.A.C.; Crowe, J.H. Anhydrobiosis in nematodes: Carbohydrate and lipid metabolism during dehydration. J. Exp. Zool. 1975, 193, 335-342.

22. Treonis, A.M.; Wall, D.H.; Virginia, R.A. The use of anhydrobiosis by soil nematodes in the Antarctic Dry Valleys. Funct. Ecol. 2000, 14, 460-467.

23. Crowe, J.H.; Hoekstra, F.A.; Crowe, L.M. Anhydrobiosis. Annual Rev. Physiol. 1992, 54, 579-599.

24. Treonis, A.M.; Wall, D.H.; Virginia, R.A. Invertebrate biodiversity in Antarctica Dry Valley soils and sediments. Ecosystems 1999, 2, 482-492.

25. Adams, B.J.; Wall, D.H.; Gozel, U.; Hogg, I.D. The southernmost worm, Scottnema lindsayae (Nematoda): diversity, dispersal and ecological stability. Polar Biol. 2006, 30, 809-815.

26. Steinberger, Y.; Liang, W.; Savinka, E.; Meshi, T.; Barness, G. Nematode community composition and diversity associated with a topoclimatic transect in a rain shadow desert. Eur. J. Soil Biol. 2001, 37, 315-320.

27. Powers, L.E.; Ho, M.; Freckman, D.W.; Virginia, R.A. Distribution, community structure, and microhabitats of soil invertebrates along an elevational gradient in Taylor Valley, Antarctica. Arctic Alpine Res. 1998, 30, 133-141.

28. Bryant, J.; Lamanna, C.; Morlon, H.; Kerkhoff, A.J.; Enquist, B.J.; Green, J.L. Microbes on mountainsides: Contrasting elevational patterns of bacterial and plant diversity. Proc. Natl. Acad. Sci. USA 2008, 105, 11505-11511. 
29. Singh, D.; Takahashi, K.; Kim, M.; Chun, J.; Adams, J.M. A hump-backed trend in bacterial diversity with elevation on Mount Fuji, Japan. Microb. Ecol. 2012, 63, 429-437.

30. Kushner, D.J. The Halobacteriaceae, In The Bacteria; Woese, C.R., Wolfe, R.S., Eds.; Academic Press, Inc.: New York, NY, USA, 1985; Volume 8, pp. 171-214.

31. Fierer, N.; Breitbart, M.; Nulton, J.; Salamon, P.; Lozupone, C.; Jones, R.; Robeson, M.; Edwards, R.A.; Felts, B.; Rayhawk, S.; et al. Metagenomic and small-subunit rRNA analyses reveal the genetic diversity of bacteria, archaea, fungi, and viruses in soil. Appl. Environ. Microb. 2007, 73, 7059-7066.

32. Gamfeldt, L.; Hillebrand, H.; Jonsson, P.R. Species richness changes across two trophic levels simultaneously affect prey and consumer biomass. Ecol. Lett. 2005, 8, 696-703.

33. Behmer, S.T.; Joern, A. Coexisting generalist herbivores occupy unique nutritional feeding niches. Proc. Natl. Acad. Sci. USA. 2008, 105, 1977-1982.

34. Zibilske, L.M. Carbon mineralization. In Methods of Soil Analysis, Part 2: Microbiological and Biochemical Properties; Weaver, R.W., Ed.; Soil Science Society of America, Madison, WI, USA, 1994; pp. 835-863.

35. Freckman, D.W.; Baldwin, J.G. Nematoda. In Soil Biology Guide; Dindal, D.L., Ed.; John Wiley \& Sons: New York, NY, USA, 1990; pp. 155-200.

36. Yeates, G.W.; Bongers, T.; de Goede, R.G.M.; Freckman, D.W.; Georgieva, S.S. Feeding-habits in soil nematode families and genera - an outline for soil ecologists. J. Nematol. 1993, 25, 315-331.

37. Jenkins, W.R. A rapid centrifugal-flotation technique for separating nematodes from soil. Plant Dis. Rep. 1964, 48, 692.

38. Blaxter, M.L.; de Ley, P.; Garey, J.; Liu, L.X.; Scheldeman, P.; Vierstraete, A.; Vanfleteren, J.R.; Mackey, L.Y.; Dorris, M.; Frisse, L.M.; et al. A molecular evolutionary framework for the phylum Nematoda. Nature 1998, 392, 71-75.

39. Okada, H.; Oba, H. Comparison of nematode community similarities assessed by polymerase chain reaction-denaturing gradient gel electrophoresis (PCR-DGGE) and by morphological identification. Nematology 2008, 10, 689-700.

40. Muyzer, G.; Teske, A.; Wirsen, C.O.; Jannasch, H.W. Phylogenetic relationships of Thiomicrospira species and their identification in deep-sea hydrothermal vent samples by denaturing gradient gel-electrophoresis of $16 \mathrm{~S}$ rDNA fragments. Arch. Microbiol. 1995, 164, $165-172$.

41. Manganelli, M.; Malfatti, F.; Samo, T.J.; Mitchell, B.G.; Wang, H.; Azam, F. Major role of microbes in carbon fluxes during austral winter in the southern Drake Passage. PLoS One 2009, 4, 1-11.

42. DeLong, E.F. Archaea in coastal marine environments. Proc. Natl. Acad. Sci. USA 1992, 89, 5685-5689.

43. Raskin, L.; Stromley, J.M.; Rittmann, B.E.; Stahl, D.A. Group-specific 16S rRNA hybridization probes to describe natural communities of methanogens. Appl. Environ. Microbiol. 1994, 60, $1232-1240$.

(C) 2012 by the authors; licensee MDPI, Basel, Switzerland. This article is an open access article distributed under the terms and conditions of the Creative Commons Attribution license (http://creativecommons.org/licenses/by/3.0/). 